УДК 535-47

DOI: $10.18384 / 2310-7251-2017-4-88-94$

\title{
CIRCULAR DICHROISM METER BASED ON POLARIZATION DIFFRACTIVE WAVEPLATE ${ }^{1}$
}

Hakobyan Nune ${ }^{1}$, Margaryan Hakob ${ }^{1}$, Chilingaryan Hakob ${ }^{1}$, Tabiryan Nelson ${ }^{2}$, Belyaev Victor ${ }^{3}$, Solomatin Aleksey ${ }^{3}$

1 Yerevan State University 1 Alex Manoogian, Yerevan 0025, Republic of Armenia

${ }^{2}$ Beam Engineering for Advanced Measurements Co. (BEAM Co.) Winter Park, Florida 32789, USA

${ }^{3}$ Moscow Region State University 10A ul. Radio, Moscow 105005, Russian Federation

Abstract. Circular dichroism (CD) is an important parameter, characterizing optically active medium. The devices for $C D$ measurements presented on today market measures $C D$ in wide spectral range. The high-precision standard optics, electronics and optomechanics are used in these devices, and data processing requires the application of a complex mathematical apparatus. These devices are quite expensive, have large dimensions, require specially trained staff, and measurement duration is tens of minutes. In this work we present a device for $C D$ measurement on only one wavelength, the key element of which is polarization diffractive waveplate, the optical element of new generation. Device has a number of advantages: easy to use, compact, working in real time, and low cost. These advantages make it ideal for educational programs.

Key words: Optical activity, circular dichroism, spectropolarimeter, real time measurements.

\section{ПРИБОР ДЛЯ ИЗМЕРЕНИЯ КРУГОВОГО ДИХРОИЗМА НА ОСНОВЕ ПОЛЯРИЗАЦИОННОЙ ДИФРАКЦИОННОЙ ВОЛНОВОЙ ПЛАСТИНЫ}

Акопян Н.Г. ${ }^{1}$, Маргарян АЛ. ${ }^{1}$, Чилингарян А.С ${ }^{1}$, Табирян Н.В. ${ }^{2}$, Беляев В.B. ${ }^{3}$, Соломатин А.C. ${ }^{3}$

${ }_{1}$ Ереванский государственный университет ул. А. Манукяна, 1, Ереван 0025, Армения

${ }^{2}$ Компания БИМКО Винтер Парк, Орландо, Флорида, 32789, США

${ }^{3}$ Московский государственный областной университет 105005, г. Москва, улица Радио, 10А, Российская Федерация

\footnotetext{
1 This work was supported by State Committee Science MES RA, in frame of the research project № SCS 15T-1C157 / Исследование выполнено при финансовой поддержке Государственного комитета по науке МОН РА в рамках научного проекта № SCS 15T-1C157.
}

() Акопян Н.Г., Маргарян А.Л., Чилингарян А.С, Табирян Н.В., Беляев В.В., Соломатин А.С., 2017. 
Аннотация. Круговой дихроизм (КД) является важным параметром, характеризующим оптически активную среду. Измерение кругового дихроизма широко используется в физике, химии, биологии, пищевой и фармацевтической промышленности. Соответственно, данная тема включена в учебные программы высших учебных заведений.

Представленные сегодня на рынке приборы измеряют КД в широком спектральном диапазоне и предусмотрены для исследований (спектрополяриметры). В них используется высокоточная стандартная оптика, электроника и оптомеханика, а обработка данных требует применения сложного математического аппарата. Эти приборы довольно дорогие, имеют большие размеры; требуется специально обученный персонал для проведения измерений, продолжительность которых составляет десятки минут.

Создание в последние годы оптических элементов нового, четвёртого поколения, сделало возможным разработку спектрополяриметров на принципиально новой основе. Однако достаточная точность измерений в этих устройствах обеспечивается либо при больших значениях КД (сотни миллиградусов), либо в узком спектральном диапазоне.

В данной работе представлен прибор для измерения КД только на одной длине волны, ключевым элементом которого является поляризационная дифракционная волновая пластина. Прибор имеет ряд преимуществ: лёгок в использовании, компактен, функционирует в реальном времени и имеет невысокую стоимость. Эти преимущества делают прибор идеальным для применения в учебных программах.

Ключевые слова: оптическая активность, круговой дихроизм, спектрополяриметр, измерения в реальном времени.

\section{Introduction}

\section{Optical activity and circular dichroism}

Circular dichroism (CD) is an important parameter, characterizing optically active medium. The vast majority of biological substances are optically active, i.e. they rotate the plane of polarized light. Optical activity is conditioned by asymmetric structure of molecules - left and right rotations, which are optical isomers. Their physiological and biochemical effects on human body are often quite different. For example, organism does not accept proteins artificially synthesized from D-amino acids: bacteria mix only one of the isomers, absolutely not interacting with each other.

The subject of optical activity impacts on various areas of science, ranging from classical optics to elementary particle physics, cosmology and origin of life. The main physical parameters which characterized the optically active substances are optical rotation dispersion (ORD) and CD. ORD spectroscopy is especially useful for assigning the conformation of sugars. CD spectroscopy is highly important means for study of biological molecules, their structure and interactions with other molecules. CD measurement is widely used in physics, chemistry, biology, food and pharmaceutical industries; therefore, this topic is included in university curriculum.

\section{Devices for CD measuring}

$\mathrm{CD}$ measurement in wide spectral range is realized by spectropolarimeters $[3 ; 5$; 7; 10-13]. The basic functional element of modern spectropolarimeters [www.jascoinc.com, www.photophysics.com] is photoelastic modulator, by means of which the 
left- and right-circularly polarized components of light passed through the sample, are separated in time. Such method is accompanied by high losses of light intensity. That is why the powerful light sources (hundreds of Watts) and high sensitive detectors are used in these devices. In addition, to ensure high accuracy of measurement and high values of signal/noise ratio the complex mathematical approximations and long time data accumulation and processing are required. These devices are high-precision and quite expensive, have large dimensions and require specially trained staff.

Only after synthesis of new liquid crystal (LC) polymers [1] a few years ago, and creation of optical elements of a new generation [8;9] on their base, it has become possible to review the basis of optical instrument engineering. One of such elements is a polarization diffractive waveplate (PDW), which allows the registration of circular dichroism in real time. The important feature of PDW is the fact that at the its output the spatialy separated left- and right-circularly polarized components are formed, and the diffraction efficiency can be up to $100 \%$. The usage of PDW allows developing small-size, operating in real time, spectropolarimeters with simplified registration part, functioning in real time $[2 ; 4 ; 6]$. However, as our laboratory testing shows the sufficient measurement accuracy in these devices is provided either for large values of CD (hundreds of millidegrees) or in a narrow spectral range.

In this work we present a device for CD measurement on only one wavelength, the key element of which is polarization diffractive waveplate [8].

\section{Results and Discussion}

The schematic of developed device is shown in fig. 1. The monochromatic light beam passing through a cuvette, filled with the sample with CD is being spatially separated by the PDW into the left- and right-hand circularly polarized components. The intensities of those components are being recorded by the two single-active area photodetectors. The photocurrents from photodetectors are recorded by a differential logarithmic impedance amplifier, and through the controller are sent to the computer, where further processing of the recorded data takes place using specially designed software.

A quartz cuvette is used for a sample placement. If the front and back walls of the cuvette are not perfectly parallel, the additional systematic error of CD measurement

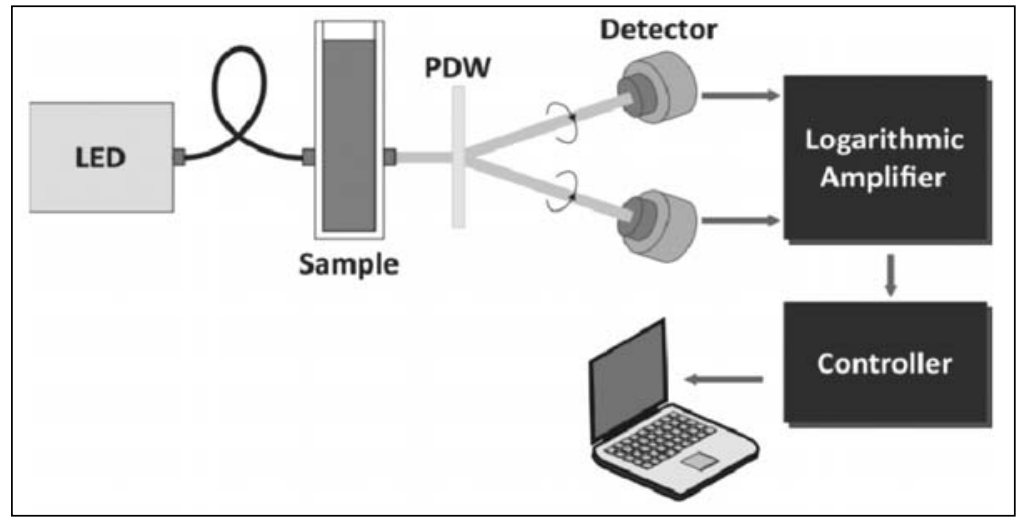

Fig. 1. Schematic of developed CD meter 


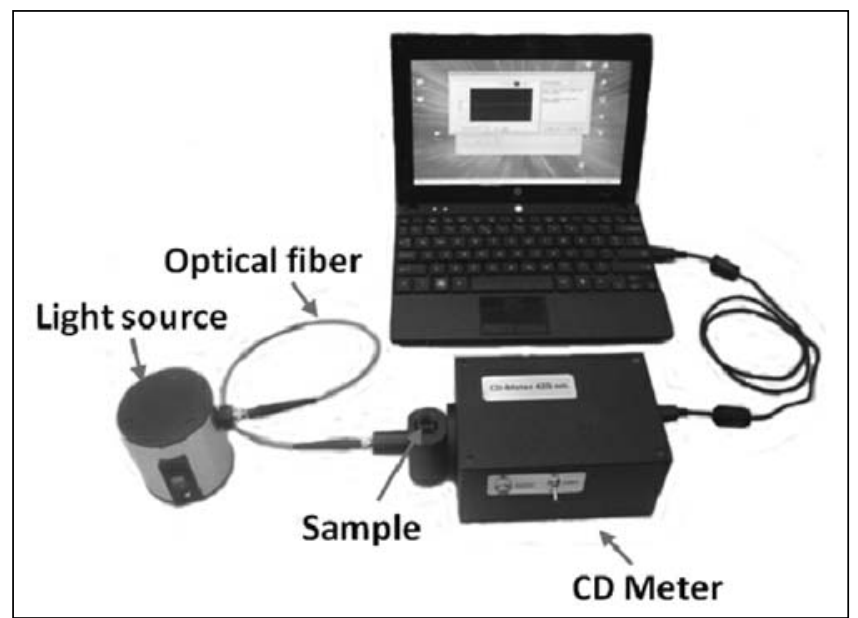

Fig. 2. External view of developed CD meter

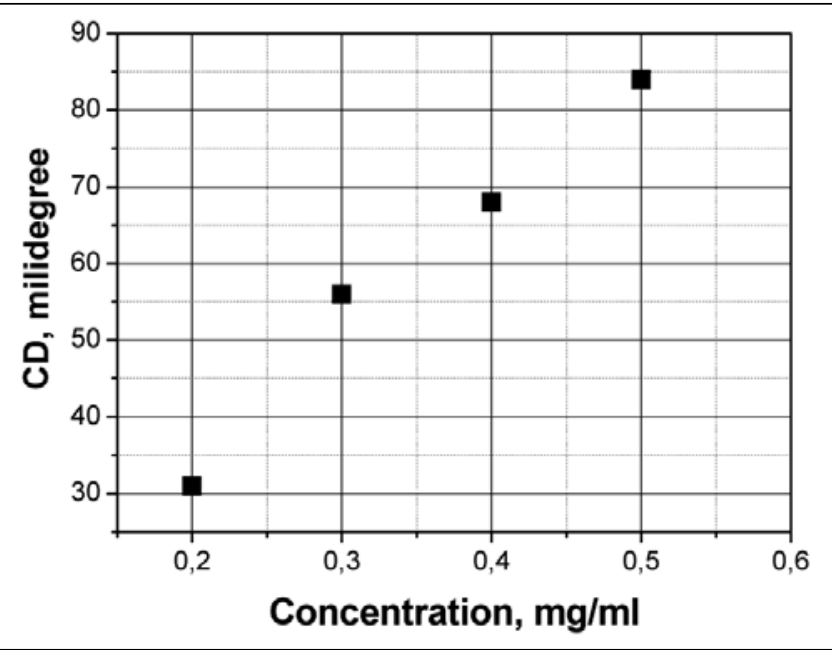

Fig. 3. CD of aqueous solution of vitamin B12 of different concentrations, measured on developed CD meter

will be added. To avoid this error the intensities of the left- and right-circularly polarized components of the beam passed through an empty cuvette and spatially separated by PDW are measured in advance. This systematic error is being accounted in software during data collection and processing.

A narrow spectral bandwidth LED is used as the light source. Alternatively, a monochromatic light beam may be formed from a wide spectral bandwidth light source, for example a xenon lamp, using a monochromator or from white light source coupled to narrow spectral bandwidth filters. A laser operating at the required light wavelengths may be used as a light source also.

The external view of device is presented on the fig. 2. To test the developed CD meter the $\mathrm{CD}$ values of aqueous solution of vitamin B12 of different concentrations have been measured at $420 \mathrm{~nm}$ wavelength (fig. 3). 
The laboratory testing of developed device was carried out by the authors, the results of which are given in fig. 3. The aqueous solution of Vitamin B-12 with $0.4 \mathrm{mg} / \mathrm{ml} \mathrm{con-}$ centration was chosen as a sample.

As it seen from the fig. 3, the CD value proportionally growths with the increasing of vitamin B12 concentration in aqueous solution. There is a good coincidence of measurement results with the literature data. For example, $\mathrm{CD}$ of aqueous solution of vitamin B12 with $0.2 \mathrm{mg} / \mathrm{ml}$ concentration at $420 \mathrm{~nm}$ wavelength is about $20 \mathrm{mdeg}$ (www.photophysics.com).

\section{Conclusion}

\section{$\underline{\text { Advantages and field of application }}$}

Methods based on optical activity measurement, are widely used in physical, chemical, biological researches and in industry. Purely technical difficulties in CD measuring have been overcome only recently, so CD method can be considered as new. Devices for CD measuring, presented in today market, are high-precision, expensive and are intended only for scientific research. A complex mathematical apparatus for data processing and high-precision optics are used in them. CD measurement is realized in wide spectral range and lasts tens of minutes.

Specificity of proposed technology is the usage of new generation optical element polarization diffraction waveplate, realized on the base of novel materials (liquid crystal polymers) by using innovative optical recording methods. PDW allows simultaneously spatially separating of linearly polarized beam to left and right circularly polarized components. This makes possible to simplify the registration part of the device, making it easy to use, compact, inexpensive, operating in real time. These advantages make the device very attractive for the universities for teaching and laboratory works on biology, biophysics and biochemistry, optics, pharmacology and organic chemistry. Such a device may be widly used in pharmaceutics also for intermediate control of production.

\section{REFERENCES}

1. Chigriniv V., Kozenkov V., Kwok H.-S. Photoalignment of Liquid Crystalline Materials: Physics and Applications. John Wiley \& Sons. 2008. 250 p.

2. Cipparone G., Pagliusi P., Provenzano C., Mazzulla A. Method and device for measuring circular dichroism in real time. PCT/IT2008/0003334, Patent No. WO 2008/142723 A2, 2008 Available at: https://www.google.com/patents/WO2008142723A2?cl=en

3. Fasman G.D. Circular Dichroism and Conformational Analysis of Biomolecules. New York, Plenum Press, 1996. 695 p. ISBN 978-1-4757-2508-7

4. Hakobyan N., Margaryan H., Hovhannisyan D., Sargsyan T., Gasparyan P., Aroutiounian V., Chilingaryan H., Pokhsraryan D., Tabiryan N. [Technique for Spectropolarimetry Based on Liquid Crystal Polarization Diffraction Grating]. In: Molecular Crystals \& Liquid Crystals, 2015, vol. 615, pp. 63-69.

5. Leyden D.E. Continuous concentration monitoring by circular dichroism. Patent US 5036204 A, 1991. Available at: https://www.google.com/patents/US5036204

6. Margaryan H., Hakobyan N., Hovhannisyan D., Aroutiounian V., Tabirian N., Rohatgi U., Jo Jae, Goushcha O., Sargsyan T., Gasparyan P. Device and method for measuring circular 
dichroism. PCT/AM/2014/000003, Patent No. WO 2016/000001 A1, 2016. Available at: https://www.google.com/patents/WO2016000001A1?cl=en

7. Nafie L.A. Dual circular polarization modulation spectrometer. Patent US 6480277B1, 2001. Available at: https://patents.google.com/patent/US6480277B1/en

8. Nersisyan S., Tabiryan N., Hoke L., Steeves D., Kimball B. [Polarization insensitive imaging through polarization gratings].In: Optics Express, 2009, vol. 17, no. 3, pp. 1817-1830.

9. Nersisyan S., Tabiryan N., Steeves D., Kimball B. [Fabrication of liquid crystal polymer axial waveplates for UV-IR wavelengths]. In: Optics Express, 2009, vol. 17, no. 14, pp. 11926-11934.

10. Saeva F.D. Method for altering elliptically polarized light. Patent US 3957346, 1976. Available at: https://www.google.com.pg/patents/US3957346

11. Sproul D.P. Differential circular dichroism measuring apparatus. Patent US 3602597, 1971. Available at: https://www.google.ch/patents/US3602597

12. Takahashi H., Kudora R., Harada T. Method and device for measuring circular dichroism spectra. Patent US 8542357B2, 2013. Available at: https://www.google.com/patents/ US8542357

13. Walsh P., Hayes A.T., Harrison D.A. Methods and apparatus for vacuum ultraviolet (VUV) or shorter wavelength circular dichroism spectroscopy. Patent US 8773662B2, 2014. Available at: https://www.google.com/patents/US8773662

\section{INFORMATION ABOUT THE AUTHORS}

Nune H. Hakobyan - junior researcher at the Department of Semiconductor Physics and Microelectronics Center of Semiconductor Devices and Nanotechnologies, Yerevan State University;

e-mail: nune.hakobyan@ysu.am;

Hakob L. Margaryan - $\mathrm{PhD}$ in Physico-mathematical sciences, senior researcher at the Department of Semiconductor Physics and Microelectronics, Center of Semiconductor Devices and Nanotechnologies, Yerevan State University;

e-mail: marhakob@ysu.am;

Hakob S. Chilingaryan - junior researcher, at the Department of Semiconductor Physics and Microelectronics, Center of Semiconductor Devices and Nanotechnologies, Yerevan State University;

e-mail: nune.hakobyan@ysu.am;

Nelson V. Tabirian - Doctor in Physico-mathematical sciences, President of Beam Engineering for Advanced Measurements Co. (BEAM Co.);

e-mail: nelson@beaco.com;

Victor V. Belyaev - Doctor in Engineering sciences, professor, head of the Department of Theoretical Physics, Moscow Region State University;

e-mail: vic_belyaev@mail.ru;

Aleksei S. Solomatin - PhD in Physico-mathematical sciences, engineer of educational-scientific laboratory of theoretical and applied nanotechnology, Moscow State Regional University; e-mail: Sotrudnica_UNC@mail.ru 


\section{ИНФОРМАЦИЯ ОБ АВТОРАХ}

Акопян Нуне Грантовна - младший научный сотрудник кафедры физики полупроводников и микроэлектроники Центра полупроводниковых приборов и нанотехнологий Ереванского государственного университета;

e-mail: nune.hakobyan@ysu.am;

Маргарян Акоп Левонович - кандидат физико-математических наук, старший научный сотрудник кафедры физики полупроводников и микроэлектроники Центра полупроводниковых приборов и нанотехнологий Ереванского государственного университета; e-mail: marhakob@ysu.am;

Чилингарян Акоп Сергеевич - младший научный сотрудник кафедры физики полупроводников и микроэлектроники Центра полупроводниковых приборов и нанотехнологий Ереванского государственного университета;

e-mail: nune.hakobyan@ysu.am;

Табирян Нельсон Владимирович - доктор физико-математических наук, президент компании BEAM Co.;

e-mail:nelson@beamco.com;

Беляев Виктор Васильевич - доктор технических наук, профессор, заведующий кафедрой теоретической физики Московского государственного областного университета; e-mail: vic_belyaev@mail.ru;

Соломатин Алексей Сергеевич - кандидат физико-математических наук, инженер учебно-научной лаборатории теоретической и прикладной нанотехнологии Московского государственного областного университета;

e-mail: Sotrudnica_UNC@mail.ru

\section{ПРАВИЛЬНАЯ ССЫЛКА НА СТАТЬЮ}

Акопян Н.Г., Маргарян А.Л., Чилингарян А.С., Табирян Н.В., Беляев В.В., Соломатин А.С. Circular dichroism meter based on polarization diffractive waveplate // Вестник Московского государственного областного университета. Серия: Физика-Математика. 2017. № 4. C. 88-94.

DOI: $10.18384 / 2310-7251-2017-4-88-94$

\section{FOR CITATION}

Hakobyan N.H., Margaryan H.L., Chilingaryan H.S., Tabiryan N.V., Belyaev V.V., Solomatin A.S. Circular dichroism meter based on polarization diffractive waveplate. In: Bulletin of Moscow Region State University. Series: Physics and Mathematics. 2017. no. 4. pp. 88-94.

DOI: $10.18384 / 2310-7251-2017-4-88-94$ 